\title{
Fertilisation of Quercus seedlings inoculated with Tuber melanosporum: effects on growth and mycorrhization of two host species and two inoculation methods
}

\author{
Sergi Garcia-Barreda ${ }^{(1-2)}$, \\ Sara Molina-Grau ${ }^{(3)}$, \\ Santiago Reyna ${ }^{(4)}$
}

\begin{abstract}
Modern truffle cultivation is based on use of inoculated seedlings, which should exhibit highly colonised roots as well as a vegetative quality enhancing field plant performance. However, poor shoot and fine root growth has been a frequent issue in inoculated Quercus seedlings production. Fertilisation is a common solution in forest nurseries, but high fertilisation levels have been found to inhibit the formation of ectomycorrhizas of many fungal species. The influence of slow-release fertilisation $(52 \mathrm{mg} \mathrm{N}, 26 \mathrm{mg} \mathrm{P}$ and $36 \mathrm{mg} \mathrm{K}$ per seedling) on growth and ectomycorrhizal status of Tuber melanosporum-inoculated seedlings was evaluated. Host species Quercus ilex and Quercus faginea and inoculation methods involving root-dipping and root-powdering were tested. Fertilisation increased weight of both host species without significant detrimental effects on ectomycorrhizal colonisation, showing that it can be effectively used in inoculated seedlings production. Both host species showed similar response to fertilisation. The inoculation method affected seedling weight and ectomycorrhizal status, suggesting that some inoculant carriers are able to damage Quercus development and $T$. melanosporum colonisation. The study provided an important basis for fine-tuning the use of fertilisers in truffle-inoculated seedling production.
\end{abstract}

\section{Keywords: Fertilisation, Seedling, Nursery, Ectomycorrhizal, Inoculation}

lands, with appropriate edaphoclimatic environment for the fungus to complete its life cycle and with low EM inoculum potential (Sourzat 2008).

High quality inoculated seedlings must exhibit a root system abundantly colonised by T. melanosporum (Andres-Alpuente et al. 2014, Murat 2015). The commercial production of these seedlings is customarily done with spore inoculum, either concentrating inoculum onto fine roots or incorporating it into substrate (Chevalier \& Grente 1978, Palazón \& Barriuso 2007). With the high price of sporocarps luring

$\square$ (1) Unidad de Recursos Forestales, Centro de Investigación y Tecnología Agroalimentaria de Aragón (CITA), Avda. Montañana 930, 50059 Zaragoza (Spain); (2) Centro de Investigación y Experimentación en Truficultura de la Diputación de Huesca, Polígono Fabardo s/n, 22430 Graus (Spain); (3) Fundación Centro de Estudios Ambientales del Mediterráneo, C/ Charles Darwin 14 Parque Tecnológico, 46980 Paterna (Spain); (4) ETS Ingeniería Agronómica y del Medio Natural, Universitat Politècnica de València, Camino de Vera s/n, 46021 Valencia (Spain)

@ Sergi Garcia-Barreda (sergigarciabarreda@gmail.com)

Received: Apr 27, 2016 - Accepted: Aug 22, 2016

Citation: Garcia-Barreda S, Molina-Grau S, Reyna S (2017). Fertilisation of Quercus seedlings inoculated with Tuber melanosporum: effects on growth and mycorrhization of two host species and two inoculation methods. iForest 10: 267-272. - doi: 10.3832/ifor2096-009 [online 2016-12-13]

Communicated by: Andrea Cutini

nurserymen into reducing inoculum application rates, selection of carrier materials providing close contact with fine roots and even distribution of inoculum is critical, especially when thousands of seedlings are produced (Averseng \& Rouch 2001). For Tuber species, little scientific information is publicly available on efficiency of the various inoculation methods or on their interaction with other nursery practices, often because of patents and confidentiality agreements (Cartié et al. 2001, Pruett et al. 2008).

The quality of inoculated seedlings is determined not only by abundance of mycorrhizas but also by vegetative quality of seedlings (Fischer \& Colinas 1996). Large, nutrient-rich seedlings with high growth potential are likely to perform better in drylands with deep soils (Cortina et al. 2013), such as the agricultural lands where truffle plantations are usually established in Spain (Garcia-Barreda et al. 2007). However, problems of scarce shoot development and stunted lateral root growth have been frequent in the commercial production of Quercus seedlings inoculated with T. melanosporum (Chevalier \& Grente 1978, Averseng \& Rouch 2001). Some inoculation methods seem to exacerbate this problem (Cartié et al. 1996, Pruett et al. 2008).

In forest nurseries a common solution for low vegetative quality of seedlings is fertilisation, which increases size, nutrient storage and root growth potential (Villar-Sal- 
vador et al. 2004). However, Treseder (2004) showed that nitrogen $(\mathrm{N})$ and phosphorus $(P)$ fertilisations decrease mycorrhizal abundance in the field. In nursery experiments, high fertilisation levels have been found to inhibit the formation of ectomycorrhizas of many fungal species including T. melanosporum (Dupré et al. 1982, Beckjord et al. 1985, Walker et al. 2003, Diaz et al. 2010), although Castellano \& Molina (1989) noticed that some species are much more tolerant and that fertilisation effect was dependent on the application system, fertiliser type, dose and form. On the other side, Quoreshi \& Timmer (2000) and Rincon et al. (2007) found fertiliser doses that increased growth of containerised conifer seedling without decreasing colonisation levels of inoculated fungi from various EM species.

In this study we inoculated Quercus ilex L. and Quercus faginea Lam. with T. melanosporum. We hypothesised that a moderate fertilisation regime could improve morphological quality of seedlings while maintaining EM colonisation levels suitable for commercial purposes. We assess the effect of fertilisation on growth and EM status of seedlings, applying a dose similar to that used by Rincon et al. (2007). We compare the effect of fertilisation on Q. ilex and Q. faginea, a faster-growing species (Sanz-Pérez et al. 2007), and we evaluate the use of fertilisation in two inoculation methods, root-dipping and root-powdering, both applying inoculum onto roots, although with different carrier materials. We hypothesised that host species and inoculation method would affect fine root traits, thus influencing EM status and ability of seedlings to respond to fertilisation.

\section{Materials and methods}

\section{Fungal inoculum, plant material and inoculation}

The sporocarps used as inoculum were acquired fresh and mature from plantations in Sistema Ibérico mountain range (eastern Spain). For each experiment, at least 20 sporocarps from five plantations were used in order to minimise spore germinability differences. They were surface sterilised with sodium hypochlorite solution, sliced thin, air dried under room conditions and homogenised with a coffee grinder (Palazón \& Barriuso 2007).

We selected Q. ilex as host plant because it is the most used species in Spanish truffle plantations. It was compared to $Q$. faginea, which also produces truffles in the wild and is frequently used in Spanish truffle plantations. While having biological features similar to Q. ilex, Q. faginea is a fastergrowing species whose nursery seedlings show more extensive lateral roots (Silla \& Escudero 2004, Sanz-Pérez et al. 2007). Acorns from the provenance regions Sistema Ibérico (for Q. ilex) and Sistema Ibérico Levantino (for Q. faginea) were acquired. They were surface sterilised with a $20 \%$ so- dium hypochlorite solution for five minutes, and germinated in January in a tray with perlite and vermiculite. When seedlings had 6-8 leaves and had formed lateral roots (12 weeks after seedling emergence, in late April), they were removed from the tray, mechanically root-pruned at the tap root end to eliminate its defects (Palazón \& Barriuso 2007), inoculated, and transplanted to Quick-pot ${ }^{\circledast}$ containers $(650 \mathrm{ml}, 18 \mathrm{~cm}$ deep).

The inoculation was performed by rootdipping, following a traditional method described by Hall et al. (2007) as frequently used in Spain. The bare roots were dipped in a slurry of homogenised sporocarps in a sucrose solution (2:1 water: sucrose $\mathrm{v} / \mathrm{w}$ ) aimed to produce a high viscosity suspension. The spore concentration in the slurry was adjusted to obtain an application rate of $2.0 \mathrm{~g}$ fresh truffle per seedling $\left(6 \times 10^{5}\right.$ spores per seedling), although some variability between seedlings is impossible to avoid due to differing levels of fine root development. This method is compared to a root-powdering inoculation, also concentrating spores onto roots but with a solid carrier instead of a liquid one (Cartié et al. 2001). A mix of talcum powder (hydrated magnesium silicate) and homogenised sporocarps was applied onto seedling bare roots, with spore concentration adjusted to obtain an inoculum rate of $2.0 \mathrm{~g}$ fresh truffle per seedling.

The potting substrate consisted of 12:6:1 $(v / v)$ calcareous sandy loam soil, base-fertilised Sphagnum white peat (Kekkila ${ }^{\circledR}$ White $420 \mathrm{~W}$ ), and limestone coarse sand. It was solarised during summer, and subsequently presented a $\mathrm{pH}$ of 7.9 , conductivity (1:5) of $418 \mathrm{mS} \mathrm{m}^{-1}, 1390 \mathrm{ppm} \mathrm{N}$ (Kjeldahl), 32 ppm P (Olsen) and 337 ppm K (ammonium acetate extraction), with $\mathrm{pH}$ and nutrient levels falling within the common range in Spanish wild truffle soils (GarciaBarreda et al. 2007). A soil-based potting mix was selected because these are still used with good results in truffle nurseries and research (Cartié et al. 2001, Benucci et al. 2012). Seedlings were cultivated in a greenhouse and sprinkle irrigated to saturation 2-3 times per week during summer and once each 7-14 days during winter.

Following the first shoot flush after inoculation (seven weeks after inoculating, in mid June), slow-release fertiliser Osmocote Exact Mini ${ }^{\oplus}$ (NPK $16-8-11$, with a longevity of 3-4 months at $21^{\circ} \mathrm{C}$ ) was added in the surface of substrate at a dose $0.5 \mathrm{~g} \mathrm{~L}^{-1}$, providing $52 \mathrm{mg} \mathrm{N}, 26 \mathrm{mg} \mathrm{P}, 36 \mathrm{mg} \mathrm{K}, 6.5 \mathrm{mg}$ $\mathrm{Mg}, 1.3 \mathrm{mg}$ chelated $\mathrm{Fe}, 0.16 \mathrm{mg} \mathrm{Mn}$ and $\mathrm{Cu}, 0.07 \mathrm{mg} \mathrm{B}$ and Mo and $0.06 \mathrm{mg} \mathrm{Zn}$ per seedling. We selected a slow-release fertiliser because it is the most common in Spanish forest nurseries. The dose was selected following that used by Rincon et al. (2007) for avoiding inhibition of EM formation in containerised Pinus seedlings.

\section{Experimental design}

Two experiments were done indepen- dently. In 2009 an experiment to compare the effect of fertilisation on two host species (Q. ilex and Q. faginea) was conducted. Four treatments were established in a $2 \times 2$ factorial design, with 12 replicates per treatment: unfertilised Q. ilex, fertilised Q. ilex, unfertilised $Q$. faginea and fertilised $Q$. faginea. All seedlings were inoculated with root-dipping.

In 2010 an experiment to compare the effect of fertilisation on two inoculation methods was conducted. Four treatments were established in a $2 \times 2$ factorial design, with six replicates per treatment: unfertilised root-dipping, fertilised root-dipping, unfertilised root-powdering and fertilised root-powdering. The experiment was conducted with Q. ilex as plant host.

\section{Data collection and analysis}

The seedlings of the fertilisation and host species experiment were analysed 12 months after inoculation (in April-May), whereas the fertilisation and inoculation method experiment was analysed 11 months after inoculation (in March). The mycorrhizal status was assessed through a volumetric sampling. In each seedling a sample with $9 \%$ of the substrate volume (57 $\mathrm{ml}$ ) was taken. To cope with heterogeneity across soil depth, every sample consisted of three subsamples: the depth of the container was divided into three equal parts, and in the centre of each third (4, 9 and $13.5 \mathrm{~cm}$ depth) a horizontal core $(2 \mathrm{~cm}$ diameter) across the container was taken.

Samples were kept in water at $4^{\circ} \mathrm{C}$. Length of fine roots (diameter $<2 \mathrm{~mm}$ ) was measured according to Tennant (1975). Root tips were counted and classified as non-mycorrhizal, T. melanosporum ectomycorrhizas or contaminant ectomycorrhizas. Shoot dry weight, root dry weight, fine root dry weight, stem height and root collar diameter were measured after drying to constant weight at $80^{\circ} \mathrm{C}$.

Plant dry weight, shoot and root dry weight, stem height, root collar diameter, specific root length (SRL, ratio of root length to dry weight of fine roots), number of root tips and number of T. melanosporum tips per seedling were analysed by conventional ANOVA. Proportion of root tips colonised by T. melanosporum and frequency of occurrence of contaminants in seedlings were analysed through generalised (binomial) linear models. When model assumptions were violated, the response variable was transformed. In the model for proportion of roots colonised by T. melanosporum, fine root length was included as a covariate to account for within-treatment variability in fine root development.

\section{Results}

\section{Experiment 1: fertilisation/host species}

Total dry weight of seedlings was positively affected by fertilisation $(P<0.001)$, with no significant differences between host species $(P=0.50-$ Tab. 1$)$. Both shoot 
Tab. 1 - Mean growth and mycorrhizal levels in Experiment 1: fertilisation/host species (95\% confidence interval in parentheses). Let ters indicate significant differences $(\alpha=0.05)$ between treatments according to the respective ANOVA or linear model. ( $($ ): Variables log-transformed.

\begin{tabular}{|c|c|c|c|c|}
\hline \multirow{2}{*}{ Variable } & \multicolumn{2}{|c|}{ Host species } & \multicolumn{2}{|c|}{ Fertilisation regime } \\
\hline & Q. ilex & Q. faginea & Unfertilised & Fertilised \\
\hline Plant dry weight (g) & $\begin{array}{c}5.34 \\
(4.79,5.90)\end{array}$ & $\begin{array}{c}5.61 \\
(5.05,6.17)\end{array}$ & $\begin{array}{c}4.06^{j} \\
(3.51,4.62)\end{array}$ & $\begin{array}{c}6.89^{i} \\
(6.34,7.45)\end{array}$ \\
\hline Shoot dry weight $(\mathrm{g})^{\mathrm{s}}$ & $\begin{array}{c}1.51 \\
(1.32,1.75)\end{array}$ & $\begin{array}{c}1.44 \\
(1.25,1.66)\end{array}$ & $\begin{array}{c}1.02^{\mathrm{j}} \\
(0.89,1.17)\end{array}$ & $\begin{array}{c}2.144^{i} \\
(1.86,2.46)\end{array}$ \\
\hline Root dry weight (g) ${ }^{5}$ & $\begin{array}{c}3.50 \\
(3.13,3.91)\end{array}$ & $\begin{array}{c}3.71 \\
(3.32,4.14)\end{array}$ & $\begin{array}{c}2.88^{\mathrm{j}} \\
(2.57,3.21)\end{array}$ & $\begin{array}{c}4.50^{i} \\
(4.03,5.03)\end{array}$ \\
\hline Stem height $(\mathrm{cm})$ & $\begin{array}{c}15.8 \\
(13.9,17.7)\end{array}$ & $\begin{array}{c}15.3 \\
(13.4,17.1)\end{array}$ & $\begin{array}{c}12.5^{j} \\
(10.6,14.4)\end{array}$ & $\begin{array}{c}18.6^{i} \\
(16.7,20.5)\end{array}$ \\
\hline Root collar diameter $(\mathrm{mm})$ & $\begin{array}{l}6.1^{\mathrm{b}} \\
(5.7,6.6)\end{array}$ & $\begin{array}{l}7.9^{\mathrm{a}} \\
(7.5,8.4)\end{array}$ & $\begin{array}{c}6.3^{j} \\
(5.9,6.8)\end{array}$ & $\begin{array}{c}7.7^{i} \\
(7.2,8.1)\end{array}$ \\
\hline Specific root length $\left(\mathrm{m} \mathrm{g}^{-1}\right)^{\mathrm{S}}$ & $\begin{array}{c}8.4^{\mathrm{b}} \\
(7.2,9.8)\end{array}$ & $\begin{array}{c}12.3^{\mathrm{a}} \\
(10.6,14.3)\end{array}$ & $\begin{array}{c}10.9 \\
(9.3,12.7)\end{array}$ & $\begin{array}{c}9.5 \\
(8.2,11.1)\end{array}$ \\
\hline Number of root tips $\left(\times 10^{3}\right)^{5}$ & $\begin{array}{c}4.20^{\mathrm{b}} \\
(3.37,5.24)\end{array}$ & $\begin{array}{c}10.04^{\mathrm{a}} \\
(8.05,12.53)\end{array}$ & $\begin{array}{c}5.52^{\mathrm{j}} \\
(4.42,6.89)\end{array}$ & $\begin{array}{c}7.64^{i} \\
(6.12,9.53)\end{array}$ \\
\hline $\begin{array}{l}\text { Number of mycorrhizas } \\
\text { T. melanosporum }\left(\times 10^{3}\right)^{5}\end{array}$ & $\begin{array}{l}1.28^{\mathrm{b}} \\
(0.97,1.68)\end{array}$ & $\begin{array}{c}4.62^{\mathrm{a}} \\
(3.52,6.06)\end{array}$ & $\begin{array}{c}2.31 \\
(1.76,3.03)\end{array}$ & $\begin{array}{c}2.56 \\
(1.95,3.36)\end{array}$ \\
\hline $\begin{array}{l}\text { Percentage of roots colonised } \\
\text { by } T \text {. melanosporum }\end{array}$ & $\begin{array}{c}35.0^{\mathrm{b}} \\
(34.1,35.9)\end{array}$ & $\begin{array}{c}45.4^{\mathrm{a}} \\
(44.5,46.4)\end{array}$ & $\begin{array}{c}42.1 \\
(39.8,44.4)\end{array}$ & $\begin{array}{c}38.3 \\
(36.1,40.6)\end{array}$ \\
\hline $\begin{array}{l}\text { Frequency of occurrence of } S \text {. } \\
\text { brunnea }\end{array}$ & $\begin{array}{c}0.17^{\mathrm{a}} \\
(0.01,0.33)\end{array}$ & $0^{\mathrm{b}}$ & $\begin{array}{l}0.04 \\
(0,0.13)\end{array}$ & $\begin{array}{l}0.13 \\
(0,0.27)\end{array}$ \\
\hline
\end{tabular}

and root dry weight followed the same pattern, with a positive effect of fertilisation ( $\mathrm{P}<0.001$ in both cases) and no significant differences between host species $(P=0.59$ and $P=0.46$, respectively - Tab. 1$)$. Stem height was positively affected by fertilisation $(P<0.001)$, with no significant differences between host species $(P=0.69-$ Tab. 1). Root collar diameter was positively affected by fertilisation $(P<0.001)$ and higher in Q. faginea than in Q. ilex $(\mathrm{P}<0.001$ - Tab. 1). SRL was higher in Q. faginea $(P=0.001)$, with no significant effect of fertilisation ( $P=0.22$ - Tab. 1). The number of root tips per seedling was higher in $Q$. faginea $(P<0.001)$ and in fertilised seedlings $(P=0.04-$ Tab. 1$)$.
The inoculum of T. melanosporum formed mycorrhizas with all seedlings. The number of T. melanosporum mycorrhizas per seedling and the proportion of root tips colonised by $T$. melanosporum were higher in Q. faginea $(P<0.001$ and $P=0.01$, respectively), with no significant effect of fertilisation ( $P=0.59$ and $P=0.24$, respectively Tab. 1). The only contaminant EM species found in seedlings was Sphaerosporella brunnea Svrcek and Kubicka, showing a higher occurrence frequency on $Q$. ilex $(P=0.02)$ and no significant effect of fertilisation ( $P=0.22$ - Tab. 1). The mean proportion of root tips colonised by S. brunnea on Q. ilex was $2.5 \%$.

The distribution of T. melanosporum colo- nisation levels along the depth profile did not show any significant $(\alpha=0.05)$ interaction with fertilisation.

\section{Experiment 2: fertilisation/inoculation} method

Total dry weight of seedlings, shoot dry weight and root dry weight were higher in root-powdering inoculation than in rootdipping $(P=0.004, P=0.003$ and $P=0.02$, respectively). No significant effect of fertilisation was found $(\mathrm{P}=0.08, \mathrm{P}=0.14$ and $\mathrm{P}=0.08$, respectively), although the trend with respect to fertilisation was the same as in the fertilisation/host species experiment (Tab. 2). Stem height was not significantly affected by either fertilisation $(P=0.28)$ or

Tab. 2 - Mean growth and mycorrhizal levels in Experiment 2: fertilisation/inoculation method (95\% confidence interval in parentheses). Letters indicate significant differences $(\alpha=0.05)$ between treatments according to the respective ANOVA or linear model. ( () : Variables log-transformed.

\begin{tabular}{|c|c|c|c|c|}
\hline \multirow{2}{*}{ Variable } & \multicolumn{2}{|c|}{ Inoculation method } & \multicolumn{2}{|c|}{ Fertilisation regime } \\
\hline & Root-dipping & Root-powdering & Unfertilised & Fertilised \\
\hline Plant dry weight $(\mathrm{g})^{\mathrm{s}}$ & $\begin{array}{c}3.54^{\mathrm{b}} \\
(3.09,4.05)\end{array}$ & $\begin{array}{c}4.73^{a} \\
(4.14,5.41)\end{array}$ & $\begin{array}{c}3.76 \\
(3.29,4.30)\end{array}$ & $\begin{array}{c}4.45 \\
(3.89,5.09)\end{array}$ \\
\hline Shoot dry weight $(\mathrm{g})^{\mathrm{s}}$ & $\begin{array}{c}1.19^{\mathrm{b}} \\
(1.01,1.40)\end{array}$ & $\begin{array}{c}1.72^{\mathrm{a}} \\
(1.46 .2 .02)\end{array}$ & $\begin{array}{c}1.31 \\
(1.11,1.54)\end{array}$ & $\begin{array}{c}1.56 \\
(1.32,1.83)\end{array}$ \\
\hline Root dry weight $(\mathrm{g})^{\mathrm{s}}$ & $\begin{array}{c}2.33^{\mathrm{b}} \\
(2.03,2.68)\end{array}$ & $\begin{array}{c}2.99^{\mathrm{a}} \\
(2.60,3.44)\end{array}$ & $\begin{array}{c}2.42 \\
(2.10,2.78)\end{array}$ & $\begin{array}{c}2.88 \\
(2.51,3.31)\end{array}$ \\
\hline Stem height $(\mathrm{cm})$ & $\begin{array}{c}14.8 \\
(12.0,17.5)\end{array}$ & $\begin{array}{c}16.9 \\
(14.2,19.6)\end{array}$ & $\begin{array}{c}14.8 \\
(12.1,17.5)\end{array}$ & $\begin{array}{c}16.9 \\
(14.1,19.6)\end{array}$ \\
\hline Root collar diameter $(\mathrm{mm})$ & $\begin{array}{c}5.7 \\
(5.3,6.1)\end{array}$ & $\begin{array}{c}6.1 \\
(5.7,6.5)\end{array}$ & $\begin{array}{l}5.6^{j} \\
(5.1,6.0)\end{array}$ & $\begin{array}{c}6.3^{i} \\
(5.9,6.7)\end{array}$ \\
\hline Specific root length $\left(\mathrm{m} \mathrm{g}^{-1}\right)$ & $\begin{array}{c}23.6 \\
(20.9,26.2)\end{array}$ & $\begin{array}{c}22.6 \\
(19.9,25.2)\end{array}$ & $\begin{array}{c}23.6 \\
(21.0,26.3)\end{array}$ & $\begin{array}{c}22.5 \\
(19.9,25.2)\end{array}$ \\
\hline Number of root tips $\left(\times 10^{3}\right)^{5}$ & $\begin{array}{c}4.84 \\
(3.49,6.69)\end{array}$ & $\begin{array}{c}6.92 \\
(5.00,9.57)\end{array}$ & $\begin{array}{c}6.37 \\
(4.60,8.81)\end{array}$ & $\begin{array}{c}5.25 \\
(3.80,7.27)\end{array}$ \\
\hline $\begin{array}{l}\text { Number of mycorrhizas } T \text {. } \\
\text { melanosporum }\left(\times 10^{3}\right)^{\mathrm{s}}\end{array}$ & $\begin{array}{c}1.62^{\mathrm{b}} \\
(1.24,2.12)\end{array}$ & $\begin{array}{c}2.74^{\mathrm{a}} \\
(2.10,3.58)\end{array}$ & $\begin{array}{c}2.26 \\
(1.73,2.95)\end{array}$ & $\begin{array}{c}1.97 \\
(1.51,2.57)\end{array}$ \\
\hline $\begin{array}{l}\text { Percentage of roots colonised } \\
\text { by } T \text {. melanosporum }\end{array}$ & $\begin{array}{c}32.6^{\mathrm{b}} \\
(29.7,35.5)\end{array}$ & $\begin{array}{c}43.7^{\mathrm{a}} \\
(37.8,49.5)\end{array}$ & $\begin{array}{c}37.6 \\
(31.6,43.5)\end{array}$ & $\begin{array}{c}38.6 \\
(35.0,42.2)\end{array}$ \\
\hline $\begin{array}{l}\text { Frequency of occurrence of } S \text {. } \\
\text { brunnea }\end{array}$ & $\begin{array}{c}0.42^{\mathrm{a}} \\
(0.12,0.71)\end{array}$ & $0^{\mathrm{b}}$ & $\begin{array}{c}0.25 \\
(0,0.51)\end{array}$ & $\begin{array}{c}0.17 \\
(0,0.39)\end{array}$ \\
\hline
\end{tabular}


inoculation method ( $P=0.26-$ Tab. 2). Root collar diameter was positively affected by fertilisation $(P=0.02)$, with no significant differences between inoculation methods $(P=0.16$ - Tab. 2). Neither SRL nor number of root tips per seedling were significantly affected by fertilisation $(\mathrm{P}=0.54$ and $P=0.39$, respectively) or inoculation method $(P=0.59$ and $P=0.12$, respectively - Tab. 2).

The inoculum of T. melanosporum formed mycorrhizas with all seedlings. The number of $T$. melanosporum mycorrhizas per seedling and the proportion of root tips colonised by $T$. melanosporum were higher in root-powdering inoculation $(\mathrm{P}=0.009$ and $P=0.049$, respectively), with no significant effect of fertilisation ( $\mathrm{P}=0.46$ and $\mathrm{P}=0.68$, respectively - Tab. 2). The only contaminant EM species found was $S$. brunnea, showing a higher occurrence frequency in root-dipping inoculation $(\mathrm{P}=0.004)$ and no significant effect of fertilisation $(P=0.56$ Tab. 2). The mean proportion of root tips colonised by S. brunnea in root-dipping inoculation was $5.2 \%$.

The distribution of T. melanosporum colonisation levels along the depth profile did not show any significant $(\alpha=0.05)$ interaction with fertilisation.

\section{Discussion}

In modern truffle cultivation the use of inoculated seedlings is fundamental (Hall et al. 2007). The abundance of T. melanosporum mycorrhizas in the early years after plantation establishment has been found positively related to mycorrhizal abundance in the nursery and to plant performance after planting (Bourrières et al. 2005, Garcia-Barreda \& Reyna 2013). Nursery practices must be fine-tuned to encourage colonisation by $T$. melanosporum, but also to improve vegetative quality of seedlings. However, in nursery fertilisation experiments a conflict between optimal seedling growth and EM colonisation has been reported for many EM fungi (Castellano \& Molina 1989, Walker et al. 2003, Diaz et al. 2010). Two mechanisms have been suggested to explain this conflict: (i) the host reducing carbon supply to the fungus due to a greater carbon demand by growing shoots, or (ii) the fungus requiring most carbon received from the plant to assimilation of the greater $\mathrm{N}$ uptake (Wallander 1995).

The fertilisation dose used in the present study increased growth as well as vegetative quality according to Spanish standards (Villar-Salvador et al. 2012a, 2012b), while maintaining $T$. melanosporum colonisation levels. In the fertilisation/host species experiment, fertilisation increased seedling biomass by $70 \%$, stem height by $49 \%$ and root collar diameter by $22 \%$, without significant detrimental effects on fine root traits or EM colonisation levels. In the fertilisation/inoculation method experiment, fertilisation increased Q. ilex root collar diameter by $13 \%$. The lower magnitude of the fertili- sation effect in the latter experiment could be due to differences in acorn size ( $\mathrm{Na}$ varro et al. 2006), spore germinability ( $\mathrm{Pa}$ lazón \& Barriuso 2007) or greenhouse climatic conditions from year to year, although it could also be related to the lower number of replicates decreasing the accuracy of estimation.

Our results disagree with previous experiments with containerised Quercus seedlings. Beckjord et al. (1985) inoculated Quercus alba L. and Quercus rubra L. with Pisolithus tinctorius (Pers.) Coker \& Couch and Scleroderma citrinum Pers. and found that $\mathrm{N}$ and $\mathrm{P}$ fertilisation doses suitable for mycorrhizal colonisation were much lower than those needed to promote seedling growth. Dupré et al. (1982) inoculated Quercus humilis Mill. with T. melanosporum and found that $P$ fertilisation doses with increased seedling growth did not correspond with higher mycorrhizal colonisation. In Q. ilex inoculated with Paxillus involutus (Batsch) Fr., Hebeloma mesophaeum (Pers.) Quél. and Cenococcum geophilum Fr., Oliveira et al. (2010) found that a fertiliser dose moderately higher than ours decreased mycorrhizal colonisation, with no significant increase in plant biomass or shoot height. On the other hand, Rincon et al. (2007), Quoreshi \& Timmer (2000) and Khasa et al. (2001) found fertilisation levels that improved conifer growth without damaging colonisation levels by various inoculated EM fungi, supporting that at least in some cases they can be reconciled.

The contrast between our results and other Quercus experiments could be due to differences in sensitiveness of EM species to fertilisers (Castellano \& Molina 1989, Wallander 1995), differences in the response of host species to fertilisation, differences in fertilisation implementation or differences in other cultivation practices. The response of non-inoculated $Q$. ilex seedlings to fertilisation follows a pattern similar to other Mediterranean Quercus such as Q. faginea, but different from Quercus from other biomes which show lower sufficiency levels (Uscola et al. 2015). Castellano \& Molina (1989) warned that response of EM fungi to fertilisation was influenced not only by the dose but also by fertiliser type and form, as well as application system (timing, rate and method).

In our study, $Q$. ilex and $Q$. faginea showed very similar biomass and response to fertilisation, as expected for species with similar biological features and agreeing with results of Sanz-Pérez et al. (2007) for non-inoculated seedlings fertilised with $50 \mathrm{mg} \mathrm{N}$. We found the main differences between these species in fine root traits and EM status, with Q. faginea showing higher SRL, number of root tips and number of mycorrhizas. This agrees with findings of Domínguez-Núñez et al. (2006) and Silla \& Escudero (2004) in young plantations. The former found more root tips and EM tips in Q. faginea than in Q. ilex seedlings inoculated with $T$. melanosporum, whereas the latter found higher SRL in Q. faginea than in Q. ilex non-inoculated seedlings. Our results agree with the accepted view that $Q$. faginea root system is more branched and extensive.

The distinct fine root traits of Q. ilex and Q. faginea went along with differences in EM status. This could be due to the inoculation method delivering somewhat more spore inoculum to seedlings with higher SRL, to inoculum being more evenly distributed within seedling fine roots, or to seedlings recovering before from transplantation. However no interaction in the response of fine root traits to fertilisation was found, suggesting that differences between Q. ilex and Q. faginea did not affect ability of seedlings to respond to fertilisation.

The inoculation method influenced seedling weight and EM status, with root-dipping showing worse characteristics. Pruett et al. (2008) found that adding hydrogel in a water slurry for root-dipping inoculation had negative effects on Quercus robur L. survival, root development and Tuber aestivum Vittad. colonisation. Cartié et al. (1996) found that using an alginate solution for root-dipping inoculation provoked an important Q. ilex mortality and a low T. melanosporum colonisation. These results suggest that inoculant carriers forming a sticky coating around the complete root system are able to damage Quercus development and Tuber colonisation.

However, Cartié et al. (2001) found no detrimental effects of alginate solution when the inoculant was applied in a bilayer, firstly dipping roots in alginate solution and then powdering them with a mixture of inoculum and talcum. Pruett et al. (2008) found no detrimental effect of rootdipping inoculation when it was performed without hydrogel. All this suggests that the damage was due to the combination of sticky carrier and spores in close contact with roots.

Our results show that seedling characteristics and inoculation effectiveness can be affected not only by host species but also by inoculation method. Further research would help to know if fertilisation or inoculation method interact with other nursery practices.

The only EM fungi found in our study other than T. melanosporum was the pioneer, nursery adapted S. brunnea (Sánchez et al. 2014). As expected, its occurrence was higher in treatments with lower T. melanosporum colonisation levels, thus suggesting that it was related to gaps left by the latter.

The inoculation and fertilisation procedures used in the present study proved effective for obtaining EM seedlings with quality levels comparable to commercial standards. All seedlings bore T. melanosporum mycorrhizas, with all treatments showing mean colonisation levels analogous to those in commercial nurseries (Andres-Alpuente et al. 2014). All seedlings met the 
morphology standards established in relevant regulation on forest seedlings marketing (European Directive 1999/105/CE for Q. ilex and Spanish RD 289/2003 for Q. faginea).

\section{Conclusions}

This study showed that a dose of slowrelease fertiliser is able to improve growth and morphological quality of Quercus seedlings while maintaining commercial T. melanosporum colonisation levels under greenhouse conditions. Quercus ilex and Q. faginea showed differences mainly in fine root traits and EM status, but in spite of them both species showed similar response to the fertilisation dose. The inoculation method proved able to influence not only EM status but also seedling growth. The study provided an important basis for finetuning use of fertilisation in commercial production of $T$. melanosporum-inoculated seedlings, but showed that inoculation effectiveness can be altered by other cultural practices, hence the improvement of these practices should be addressed jointly.

\section{Acknowledgements}

This work was funded by Instituto $\mathrm{Na}$ cional de Investigación y Tecnología Agraria y Alimentaria (INIA, Government of Spain) project PET2007-13-C07-04.

\section{References}

Andres-Alpuente A, Sanchez S, Martin M, Aguirre AJ, Barriuso JJ (2014). Comparative analysis of different methods for evaluating quality of Quercus ilex seedlings inoculated with Tuber melanosporum. Mycorrhiza 24: S29-S37. - doi: 10.1007/s00572-014-0563-x

Averseng P, Rouch P (2001). Quatre étapes de l'amélioration d'un produit au travers d'un quart de siècle de coopération entre l'INRA et Agri-Truffe [Four steps for the improvement of a product in a quarter of century of cooperation between INRA and Agri-Truffe]. In: Proceedings of the "Vè Congrès International Science et Culture de la Truffe" (Sourzat P ed). Aix-en-Provence (France), 4-6 March 1999. Fédération Française des Trufficulteurs, Marseille, France, pp. 293-295. [in French]

Beckjord PR, Melhuish Jr JH, Mclntosh MS (1985). Effects of nitrogen and phosphorus fertilization on growth and formation of ectomycorrhizae of Quercus alba and Q. rubra seedlings by Pisolithus tinctorius and Scleroderma auranteum. Canadian Journal of Botany 63: 16771680. [online] URL: http://www.nrcresearch press.com/doi/abs/10.1139/b85-233

Benucci GMN, Gógán Csorbai A, Baciarelli Falini L, Bencivenga M, Di Massimo G, Donnini D (2012). Mycorrhization of Quercus robur L., Quercus cerris L. and Corylus avellana L. seedlings with Tuber macrosporum Vittad. Mycorrhiza 22: 639-646. - doi: 10.1007/s00572-012-04 41-3

Bourrières $D$, Coves $H$, Tixier R, Ricard $J M$ (2005). Effects of the initial level of mycorrhization of young plants inoculated with Tuber melanosporum. In: Abstracts book of "IV International Workshop on Edible Mycorrhizal
Mushrooms (IWEMM4)". Murcia (Spain) 28 Nov - 2 Dec 2005. Universidad de Murcia, Murcia, Spain, pp. 32.

Cartié G, Palazón C, Barriuso JJ, Delgado I (1996). Un nuevo método de inoculación de Quercus ilex L. por Tuber melanosporum Vitt. [A new method of Quercus ilex L. inoculation by Tuber melanosporum Vitt.]. Revista Montes 46: 40-43. [in Spanish]

Cartié G, Palazón C, Delgado I, Barriuso JJ (2001). Influencia del método de inoculación, del tipo de substrato y de la procedencia de la trufa, en la micorrización de Quercus ilex L. por Tuber melanosporum Vitt. y en la supervivencia de las plantas [Influence of inoculation method, kind of substrate and origin of truffle on Quercus ilex L. mycorrhization by Tuber melanosporum Vitt. and plant survival]. In: Proceedings of the "Vè Congrès International Science et Culture de la Truffe" (Sourzat $P$ ed). Aix-en-Provence (France) 4-6 March 1999. Fédération Française des Trufficulteurs, Marseille, France, pp 296299. [in Spanish]

Castellano MA, Molina R (1989). Mycorrhizae. In: "The Container Tree Nursery Manual, Vol. 5. The biological component: nursery pests and mycorrhizae" (Landis TD, Tinus RW, McDonald SE, Barnett JP eds). USDA Forest Service, Washington, USA, pp. 101-171.

Chevalier G, Grente J (1978). Application pratique de la symbiose ectomycorhizienne: production a grande echelle de plants mycorhizes par la truffe (Tuber melanosporum Vitt.) [Practical application of ectomycorrhizal symbiosis: large-scale production of plants mycorrhized by truffle]. Mushroom Science 10: 483-505.

Cortina J, Vilagrosa A, Trubat R (2013). The role of nutrients for improving seedling quality in drylands. New Forests 44: 719-732. - doi: 10.1007 /s11056-013-9379-3

Diaz G, Carrillo C, Honrubia M (2010). Mycorrhization, growth and nutrition of Pinus halepensis seedlings fertilized with different doses and sources of nitrogen. Annals of Forest Science 67: 405. - doi: 10.1051/forest/2009125

Domínguez-Núñez JA, Selva-Serrano J, Rodríguez-Barreal JA, Saiz de Omeñaca JA (2006). The influence of mycorrhization with Tuber melanosporum in the afforestation of a Mediterranean site with Quercus ilex and Quercus faginea. Forest Ecology and Management 231: 226-233. - doi: 10.1016/j.foreco.2006.05.052

Dupré C, Chevalier G, Morizet J, Leblevenec L (1982). Influence de l'azote et du phosphore sur la mycorhization de Quercus pubescens Willd. par Tuber melanosporum Vitt. en conditions contrôlées [Influence of nitrogen and phosphorus on mycorrhiza formation by Quercus pubescens Willd. and Tuber melanosporum Vitt. under controlled conditions]. In: "Les mycorhizes, partie intégrante de la plante: biologie et perspectives d'utilisation". (Gianinazzi S, Gianinazzi-Pearson V, Trouvelot A eds). INRA seminar no. 13, INRA, Dijon, France, pp. 147-154. [in French]

Fischer CR, Colinas C (1996). Methodology for certification of Quercus ilex seedlings inoculated with Tuber melanosporum for commercial application. In: Abstracts booklet of " " $1^{\text {st }}$ International Conference on Mycorrhizae (ICOM1)" (Szaro TM, Bruns TD eds). Berkeley (California,
USA) 4-9 Aug 1996. University of California, Berkeley, California, USA, p 34.

Garcia-Barreda S, Reyna S (2013). Cultivation of Tuber melanosporum in firebreaks: short-term persistence of the fungus and effect of seedling age and soil treatment. Fungal Biology 117: 783-790. - doi: 10.1016/j.funbio.2013.10.001

Garcia-Barreda S, Reyna S, Pérez-Badía R, Rodríguez-Barreal JA, Domínguez-Núñez JA (2007). Ecología de la trufa y las áreas truferas [Ecology of truffle and truffle areas]. In: "Truficultura: Fundamentos y Técnicas” (Reyna S ed). Ed. Mundi-Prensa, Madrid, Spain, pp. 153-208. [in Spanish]

Hall I, Brown GT, Zambonelli A (2007). Taming the truffle. Timber Press, Portland, USA, pp. 304.

Khasa PD, Sigler L, Chakravarty P, Dancik BP, Erickson L, McCurdy D (2001). Effect of fertilization on growth and ectomycorrhizal development of container-grown and bare-root nursery conifer seedlings. New Forests 22: 179-197. - doi: 10.1023/A:1015674921878

Murat C (2015). Forty years of inoculating seedlings with truffle fungi: past and future perspectives. Mycorrhiza 25: 77-81. - doi: 10.1007/ so0572-014-0593-4

Navarro FB, Jiménez N, Ripoll MA, FernándezOndoño E, Gallego E, De Simón E (2006). Direct sowing of holm oak acorns: effects of acorn size and soil treatment. Annals of Forest Science 63: 961-967. - doi: 10.1051/forest:2006079 Oliveira RS, Franco AR, Vosátka M, Castro PML (2010). Management of nursery practices for efficient ectomycorrhizal fungi application in the production of Quercus ilex. Symbiosis 52: 125-131. - doi: 10.1007/s13199-010-0092-0

Palazón C, Barriuso JJ (2007). Viveros y producción de planta micorrizada [Nurseries and production of mycorrhizal plants]. In: "Truficultura: Fundamentos y técnicas" [Trufficulture: Principles and Techniques] (Reyna S ed). Ed. MundiPrensa, Madrid, Spain, pp. 209-236.

Pruett GE, Bruhn JN, Mihail JD (2008). Colonization of Pedunculate oak by the Burgundy truffle fungus is greater with natural than with pelletized lime. Agroforesty Systems 72: 41-50. doi: 10.1007/s10457-007-9069-2

Quoreshi M, Timmer VR (2000). Growth, nutrient dynamics, and ectomycorrhizal development of container-grown Picea mariana seedlings in response to exponential nutrient loading. Canadian Journal of Forest Research 30: 191-201. - doi: 10.1139/×99-208

Reyna S, Garcia-Barreda S (2014). Black truffle cultivation: a global reality. Forest Systems 23: 317-328. - doi: 10.5424/fs/2014232-04771

Rincon A, Parlade J, Pera J (2007). Influence of the fertilisation method in controlled ectomycorrhizal inoculation of two Mediterranean pines. Annals of Forest Science 64: 577-583. doi: 10.1051/forest:2007035

Sánchez S, Gómez E, Martín M, De Miguel AM, Urban A, Barriuso J (2014). Experiments on the life cycle and factors affecting reproduction of Sphaerosporella brunnea provide evidence for rapid asexual propagation by conidiospores and for homothallism in an ectomycorrhizal competitor of cultivated truffle species. Fungal Ecology 8: 59-65. - doi: 10.1016/j.funeco.2013. 12.003 
Sanz-Pérez V, Castro-Díez P, Valladares F (2007). Uscola M, Salifu KF, Oliet JA, Jacobs DF (2015). Growth versus storage: responses of Mediterranean oak seedlings to changes in nutrient and water availabilities. Annals of Forest Science 64: 201-210. - doi: 10.1051/forest:2006104

Silla F, Escudero A (2004). Nitrogen-use efficiency: trade-offs between $\mathrm{N}$ productivity and mean residence time at organ, plant and population levels. Functional Ecology 18: 511-521. doi: 10.1111/j.0269-8463.2004.00872.x

Sourzat $P$ (2008). Principe de précaution en trufficulture [The principle of precaution in truffle cultivation]. Station d'Expérimentation sur la Truffe, Le Montat, France, pp 72. [in French] Tennant $D$ (1975). A test of a modified line intersect method of estimating root length. Journal of Ecology 63: 995-1001. - doi: 10.2307/2258617 Treseder KK (2004). A meta-analysis of mycorrhizal responses to nitrogen, phosphorus, and atmospheric $\mathrm{CO}_{2}$ in field studies. New Phytologist 164: 347-355. - doi: 10.1111/j.1469-8137.2004. 01159.x
An exponential fertilization dose-response model to promote restoration of the Mediterranean oak Quercus ilex. New Forests 46: 795812. - doi: 10.1007/s11056-015-9493-5

Villar-Salvador P, Planelles R, Enríquez E, Peñuelas-Rubira J (2004). Nursery cultivation regimes, plant functional attributes, and field performance relationships in the Mediterranean oak Quercus ilex L. Forest Ecology and Management 196: 257-266. - doi: 10.1016/j.for eco.2004.02.061

Villar-Salvador P, Nicolás-Peragón JL, HerediaGuerrero N, Uscola M (2012a). Quercus ilex L. In: "Producción y manejo de semillas y plantas forestales. Tomo II" [Production and handling of forest seeds and seedlings. Vol. II] (Pemán J, Navarro-Cerrillo RM, Nicolás-Peragón JL, PradaSáez MA, Serrada R eds). Organismo Autónomo Parques Nacionales, Ministerio de Agricultura, Alimentación y Medio Ambiente, Madrid, Spain, pp. 226-250. [in Spanish]
Villar-Salvador P, Oliet J, Heredia-Guerrero N, Uscola-M, Goicoetxea P (2012b). Quercus faginea Lam. - Quercus humilis Mill. In: "Producción y manejo de semillas y plantas forestales. Tomo II" [Production and handling of forest seeds and seedlings. Vol. II] (Pemán J, NavarroCerrillo RM, Nicolás-Peragón JL, Prada-Sáez MA, Serrada R eds). Organismo Autónomo Parques Nacionales, Ministerio de Agricultura, Alimentación y Medio Ambiente, Madrid, Spain, pp. 206-225. [in Spanish]

Walker RF, Walker RF, McLaughlin SB, Amundsen CC (2003). Interactive effects of mycorrhization and fertilization on growth, nutrition, and water relations of sweet birch. Journal of Sustainable Forestry 17: 55-80. - doi: 10.1300/Jo91v1 7no3_04

Wallander H (1995). A new hypothesis to explain allocation of dry matter between mycorrhizal fungi and seedlings in relation to nutrient supply. Plant and Soil 168-169: 243-248. - doi: 10.1007/978-94-011-0455-5_27 